\title{
Correction to: A multicentre, multi-national, double-blind, randomised, active-controlled, parallel-group clinical study to assess the safety and efficacy of PDA10 (Epoetin-Alfa) vs. Eprex ${ }^{\circledR}$ in patients with anaemia of chronic renal failure
}

Soo Kun Lim ${ }^{*}$, Bak Leong Goh², Ravindran Visvanathan³, Su Hyun Kim², Jin Seok Jeon5, Sung Gyun Kim6, Jae Hyun Chang ${ }^{7}$, Chun Soo Lim ${ }^{8}$ and Zaki Morad ${ }^{9}$

Correction to: BMC Nephrology 22, 391 (2021)

https://doi.org/10.1186/s12882-021-02601-w

Following publication of the original article [1], the authors would like to correct a spelling mistake in title and in the body of the text.

The word currently reads: Alpha

The word should read: Alfa

The title has been updated above and the original article [1] has been corrected.

\begin{abstract}
Author details
${ }^{1}$ Renal Division, Department of Medicine, Faculty of Medicine, University of Malaya, 59100 Kuala Lumpur, Malaysia. ${ }^{2}$ Serdang Hospital, Kajang, Malaysia. ${ }^{3}$ Prince Court Medical Centre, Kuala Lumpur, Malaysia. ${ }^{4}$ Chung-Ang University Hospital, Seoul, South Korea. ${ }^{5}$ Soonchunhyang University Hospital, Seoul, South Korea. ${ }^{6}$ Hallym University Sacred Heart Hospital, Anyang, South Korea. ${ }^{7}$ Gil Medical Centre, Gachon University College of Medicine, Incheon, South Korea. ${ }^{8}$ Seoul National University Boramae Medical Centre, Seoul, South Korea. ${ }^{9} \mathrm{KPJ}$ Ampang Puteri Specialist Hospital, Ampang, Malaysia.
\end{abstract}

Published online: 03 January 2022

The original article can be found online at https://doi.org/10.1186/s12882021-02601-w.

\footnotetext{
*Correspondence: limsk@ummc.edu.my

${ }^{1}$ Renal Division, Department of Medicine, Faculty of Medicine, University

of Malaya, 59100 Kuala Lumpur, Malaysia

Full list of author information is available at the end of the article
}

Reference

1. Lim et al. A multicentre, multi-national, double-blind, randomised, active-controlled, parallel-group clinical study to assess the safety and efficacy of PDA10 (Epoetin-Alfa) vs. Eprex ${ }^{\circledR}$ in patients with anaemia of chronic renal failure. BMC Nephrol. 2021;22:391. https://doi.org/10.1186/ s12882-021-02601-w.

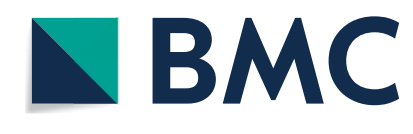

(c) The Author(s) 2021. Open Access This article is licensed under a Creative Commons Attribution 4.0 International License, which permits use, sharing, adaptation, distribution and reproduction in any medium or format, as long as you give appropriate credit to the original author(s) and the source, provide a link to the Creative Commons licence, and indicate if changes were made. The images or other third party material in this article are included in the article's Creative Commons licence, unless indicated otherwise in a credit line to the material. If material is not included in the article's Creative Commons licence and your intended use is not permitted by statutory regulation or exceeds the permitted use, you will need to obtain permission directly from the copyright holder. To view a copy of this licence, visit http://creativecommons.org/licenses/by/4.0/. The Creative Commons Public Domain Dedication waiver (http://creativeco mmons.org/publicdomain/zero/1.0/) applies to the data made available in this article, unless otherwise stated in a credit line to the data. 